\title{
Polar Auxin Transport: Understanding the Effects of Temperature and Precipitation on Polar Auxin Transport in Polytrichum Ohioense Could Develop a Moss into a Climate Change Bioindicator
}

\author{
Dorothy Belle Poli*, Bryan T. Piatkowski, Geoffrey A. Bader, Jessica N. Branning, Laura E. Kellam, \\ Matthew Corbicz, and Anne D. Wallace
}

Roanoke College, Salem, Virginia, 24153, USA

\begin{abstract}
In an attempt to better understand polar auxin transport in the sporophytes of Polytrichum ohioense, a 5.3 fold increase in basipetal and acropetal transport was observed when temperature and precipitation varied significantly throughout the growing seasons. Wild plants were transferred into cultures and allowed to develop in temperatures that represented a "Warm Summer, Cold Winter" condition. Spores were grown on soil and watered to represent precipitation of a "Wet Fall, Winter" year. Traditional polar auxin transport assays were done on all sporophytes to calculate the amount of auxin transported in a polar fashion. The amount of water available to the developing sporophyte appears to be critical to polar auxin transport physiology; the temperature has less of an effect. This study also suggests that as climate change occurs, moss will be unequally affected by the environmental factors. An additional benefit of this study suggests that polar auxin transport assays may be developed to monitor climatic change.
\end{abstract}

Keywords: Polar auxin transport, Bryophytes, Polytrichum ohioense, climate change, monitoring

\section{Introduction}

New hormones like jasmonic acid and brassinosteroids have entered plant physiology, yet it is the "classical five" hormones that are effective in all plants, including the bryophytes [1]. Indole-3-acetic acid (IAA) is recognized as the most abundant and most researched auxin [2] because in higher plants, auxin has been developmentally influential in tropic responses, inhibition of abscission, promoting fruit, apical dominance, stem elongation, root initiation, phyllotaxis, embryogenesis, and meristem development [3], [4], [5], [6], [7]. Moss gametophyte development is directly influenced by auxin metabolism, including the formation of structures such as rhizoids, thallus segments, protoplasts and protonemata [8], [9], [10], [11], [12]. Liverworts exhibit apical dominance and show increased rhizoid formation with the presence of IAA [13], [14], [15], [16], [17].

${ }^{*}$ Corresponding author. Tel.: 540-375-2461

Fax: 540-375-2447; E-mail: poli@ roanoke.edu

(c) 2014 International Association for Sharing Knowledge and Sustainability

DOI: $10.5383 /$ ijtee.07.02.009
Auxin can be transported in vascular tissue for quick and large movement or moved polarly for more control of final auxin action. Polar auxin transport (PAT) has been described by the chemiosmotic model [18], [19] which proposes that a protonsymporter is involved in cellular uptake of auxin and that this protein is affected by the uptake inhibitor 1-Naphthoxyacetic acid (NOA) [20]. Uptake of IAA is facilitated by AUX1/LIKE AUX1 (AUX1/LAX) channel proteins located all around the cell (reviewed in [6]). The unidirectional transport of IAA is determined by the polar positioning of PIN-FORMED (PIN) and MULTIDRUG RESISTANCE/P-GLYCOPROTEIN (MDR/PGP) proteins which mediate efflux [21], [22], [23], [24], [25], [26]. Auxin is the only hormone able to be transported polarly which suggests that the hormone is necessary for proper axis formation of the organism. Most would argue that auxin is the master hormone in all plants and that it's availability through transport allows a plant to regulate development [27]. PAT knowledge comes mostly from 
experiments done in higher plant model systems, such as Arabidopsis thaliana and Zea mays, however PIN proteins are known to exist in all land plants (reviewed in [28]).

Auxin transport has been reported in certain hepatics, such as Marchantia polymorpha [29], [30] however the methods employed could not distinguish between differences in uptake versus those in transport leaving questions as to the true mechanism of auxin mediation in these plants. Research has indicated that IAA has played an important part in the development and shape of all land plant sporophytes [31] yet different versions of IAA transport are utilized by bryophyte sporophytes [32]. Hornwort sporophytes transport IAA via simple, basic diffusion. Liverwort sporophytes are more complex, using apolar facilitated diffusion to move IAA. Moss sporophytes move IAA basipetally and showed sensitivity to the efflux inhibitor N-[1-naphthyl]phthalamic acid (NPA), a known PAT inhibitor in higher land plants [31], [32]. Fujita et al. [33] reported that moss gametophytes do not transport auxin polarly, however this study analyze photographic images and did not actually measure transport. Vascular plants have been shown to transport IAA basipetally, with minimal acropetal transport [18], [34]. Rothwell and Lev-Yadun [35] reported evidence of polar auxin flow in fossilized wood dating back 375 million years. These studies suggest that the increasing complexity of the sporophyte body plan required different methods of IAA transport.

Several researchers have argued that moss can be bioindicators for heavy metals on land and water [36], [37], [38] and air pollution [39], [40], [41] due to their direct connection to their immediate environment. Since bryophtyes have been shown to react to climate change (i.e. [42]) and because PAT is essential for proper development of plants, examining PAT in relation to climate change became intriguing. Because moss sporophytes are best understood in relation to PAT and because they are easily manipulated during PAT experiments, this paper examines the role of temperature and precipitation on PAT in the moss sporophyte of Polytrichum ohioense in the hopes that the assay could be used to monitor environmental change impacts.

\section{Method}

\subsection{Habit}

Polytrichum ohioense gametophytes bearing immature sporophytes were collected at the University of Maryland in College Park, Maryland, USA campus during the months of April and May and stored in the refrigerator until ready to be used; plants were removed from the refrigerator for 3 days prior to experimentation. Plants were grown on soil from the original habitat at room temperature under $100 \mu \mathrm{mol} \mathrm{m} \mathrm{m}^{-2} \mathrm{~s}^{-1}$ of fluorescent light until the sporophytes reached the desired length of $1 \mathrm{~cm}$ (referred to as 'young'). Older moss sporophytes (called 'pre-capsule') 2-3 cm in length were also used in certain experiments.

\subsection{Experiments with variable conditions}

When variations in PAT were witnessed in 2003-2004 growing season sporophytes, specifically in the basipetal direction, modifications to the above experiments were carried out to investigate changes in PAT if temperature and humidity changed. All experiments follow the below auxin transport assays protocol but sporophytes were grown under specific conditions to test the effects of temperature or humidity on PAT.

\subsubsection{Determination of temperature and precipitation trends}

Average climate data was determined for College Park MD by using the U.S. Climate Data website (http://www.usclimatedata.com/climate/collegepark/maryland/united-states/usmd0100). All control plants for the Temperature and Precipitation experiments were grown under the same conditions as the experimental plants except for the temperature or precipitation amounts. For control plants in the temperature experiment, three months to represent Spring at an average temperature of $15^{\circ} \mathrm{C}$, plants were exposed to three months to represent Summer at an average temperature of $27^{\circ} \mathrm{C}$, three months to represent Fall an average temperature of $10^{\circ} \mathrm{C}$, and three months to represent Winter at $4^{\circ} \mathrm{C}$. Control plants in the precipitation experiment were exposed to three months to represent Spring at an average rainfall of 3.2 inches each month, three months to represent Summer at an average rainfall of 4.2 inches each month, three months to represent Fall at an average rainfall of 3.2 inches each month, and three months to represent Winter at an average rainfall of 3.3 inches each month. Sporophytes in both variations were allowed to develop for another month at $15^{\circ} \mathrm{C}$ or rainfall of 3.2 inches prior to experimentation to ensure that the setae were approximately $1 \mathrm{~cm}$; capsules were not expanding.

\subsubsection{Temperature experiment}

Polytrichum ohioense sporophytes with mature capsules were collected from the wild in Roanoke VA during late May; capsules were surface sterilized using 5\% commercial Clorox and Triton X-450 (Sigma Chemical Co., St. Louis, Missouri, USA) for 10 minutes, then rinsed in a double-distilled water. The capsule was then opened with sterile forceps in a sterile Petri dish and $2.5 \mathrm{ml}$ of double distilled water was added. The resulting spore solution was spread among 6 Petri dishes of Knops media supplemented with $1 \%$ glucose, plus $1 \mathrm{~mL} / \mathrm{L}$ iron and formulation VII micronutrient solutions (Basile 1978; Sztein et al. 1999) in a 1\% Phytagar tissue culture grade agar, pH 6 (Gibco BRL, Grand Island, New York, USA). Plants were established under a $12 \mathrm{~h}$ day/night cycle, $23^{\circ} \mathrm{C}$, at 100 $\mu \mathrm{mol} \mathrm{m}^{-2} \mathrm{~s}^{-1}$. Light was provided by grow lights in a modified low temperature incubator (Fisher Scientific). Plant cultures were monitored under a microscope weekly to ensure the proper life cycle was occurring. Mature gametophytes for were established for 2 months in culture and then temperatures were regulated to represent the 2003-2004 growing season (Warm Summer, Cold Winter): three months to represent Spring at an average temperature of $15^{\circ} \mathrm{C}$, three months to represent Summer at an average temperature of $29^{\circ} \mathrm{C}$, three months to represent Fall an average temperature of $10^{\circ} \mathrm{C}$, and three months to represent Winter at $2^{\circ} \mathrm{C}$. Sporophytes were allowed to develop for another month at $15^{\circ} \mathrm{C}$ prior to experimentation to ensure that the setae were approximately 1 $\mathrm{cm}$; capsules were not expanding.

\subsubsection{Precipitation experiment}

Forty mature capsules of Polytrichum ohioense were collected in Roanoke VA, USA during late May and the spores were sprinkled onto soil and allowed to develop at $23 \mathrm{C}$, for a $12 \mathrm{~h}$ day/night cycle, at $100 \mu \mathrm{mol} \mathrm{m}^{-2} \mathrm{~s}^{-1}$ light. Light was provided by grow lights in the same chamber as the above 
experiments. Precipitation experiments were regulated by how much of an average rainfall (watering) was provided to samples. Plants were misted 3 times a week at irregular intervals to represent a "natural" rain pattern but rainfall was determined as an average to be the following for a "Wet Fall or Winter": three months to represent Spring at an average rainfall of 3.2 inches each month, three months to represent Summer at an average rainfall of 4.2 inches each month, three months to represent Fall at an average rainfall of 4.0 inches each month, and three months to represent Winter at an average rainfall of 4.2 inches each month. Sporophytes were allowed to develop for another month at a rainfall of 3.2 inches prior to experimentation to ensure that the setae were approximately $1 \mathrm{~cm}$; capsules were not expanding.

\subsection{Auxin transport assays}

Experiments to measure auxin transport in Polytrichum ohioense sporophytes were carried out as outlined in Poli et al. 2003, using conventional agar-block methods [43], [44] modified to fit small cross sectional radius of the moss. Donor blocks of $1.8 \%$ Bactoagar contained $10^{-6} \mathrm{M}[3 \mathrm{H}]-\mathrm{IAA}$ (specific activity of $25 \mathrm{Ci} / \mathrm{mmol}$, American Radiolabeled Chemicals, St. Louis, Missouri, USA), and receiver blocks were composed of water agar only. Mid-region sporophyte sections were cut 5

\subsection{Data analysis for transport experiments}

The liquid scintillation counter provided counts per minute (cpm) that were divided by the counting efficiency to yield the corresponding disintegrations per minute $(\mathrm{dpm})$. Dpm was then converted into curries $(2.2 \times 106 \mathrm{dpm}=1 \mathrm{Ci})$ and then into moles by dividing by the specific activity of the [3H]-IAA $(25$ $\mathrm{Ci} / \mathrm{mmol}$ ). The data are presented as the mean \pm the standard error among replicate sections.

\section{Results}

\subsection{Original PAT experiments and variable design}

Several years of PAT work in Polytrichum ohioense provided continuously reproducible results in young and pre-capsule sporophytes [32], but in 2003-2004 basipetal transport jumped approximately 5.4 fold in young plants when exposed to auxin at a concentration of $10^{-6} \mathrm{M}$ (Table 1). A similar trend resulted in pre-capsule plants in the acropetal direction but in this case, the amount dropped approximately 5.3 fold (Table 1). Plants were collected from the same population, stored in the same containers, and exact protocols were used. Therefore, the area's weather may have been different during the experimental time frame changing the population's development. To begin to dissect what could potentially be causing such a shift in transport amounts, we examined four years of weather data for the trials in question.

Table 1: Representative PAT in Polytrichum ohioense sporophytes that were harvested from University of Maryland at College Park, Maryland USA over three growing seasons. Young basipetal transport increases 5.5 times in year 2003-2004 plants, while acropetal transport decreases in pre-capsule plants

\begin{tabular}{|c|c|c|c|c|c|c|c|}
\hline \multirow{2}{*}{ Stage } & \multirow{2}{*}{$\begin{array}{c}\text { Transport } \\
\text { Direction }\end{array}$} & \multicolumn{2}{|c|}{$\mathbf{2 0 0 3 - 2 0 0 4}$} & \multicolumn{2}{|c|}{ 2000-2001 } & \multicolumn{2}{c|}{$\mathbf{2 0 0 1 - 2 0 0 2}$} \\
\cline { 3 - 8 } & & $\begin{array}{c}\text { Transport } \\
\text { (fmoles) }\end{array}$ & $\begin{array}{c}\text { Replicate } \\
\text { Number }\end{array}$ & $\begin{array}{c}\text { Transport } \\
\text { (fmoles) }\end{array}$ & $\begin{array}{c}\text { Replicate } \\
\text { Number }\end{array}$ & $\begin{array}{c}\text { Transport } \\
\text { (fmoles) }\end{array}$ & $\begin{array}{c}\text { Replicate } \\
\text { Number }\end{array}$ \\
\hline \multirow{2}{*}{ Young } & Basipetal & $456.0 \pm 71.3$ & 9 & $85.4 \pm 8.1$ & 15 & $54.4 \pm 7.3$ & 5 \\
\cline { 2 - 8 } & Acropetal & $2.8 \pm 0.5$ & 12 & $9.2 \pm 0.8$ & 5 & $9.2 \pm 1.3$ & 5 \\
\hline \multirow{2}{*}{$\begin{array}{c}\text { Pre- } \\
\text { Capsule }\end{array}$} & Basipetal & $54.0 \pm 25.6$ & 10 & $44.7 \pm 0.7$ & 6 & $68.2 \pm 10.8$ & 10 \\
\cline { 2 - 8 } & Acropetal & $7.0 \pm 1.4$ & 11 & $37.1 \pm 0.3$ & 6 & $77.1 \pm 18.4$ & 10 \\
\hline
\end{tabular}

Using the US Climate Data website, two variables provided testable hypotheses across the years (Figure 1). In 2000-2001 temperatures and precipitation throughout the year were average in College Park, Maryland but temperature and precipitation averages vary after 2001. Temperatures shifted from cool summers and warm winters to two years with warm summers and a cold winter. Therefore, the hotter summer, colder winter model became the basis for temperature experiments.

Examining trends in precipitation provided two possible experiments (Figure 1). Using data from 2001-2003, a wet summer could be the cause of the transport amounts changing, but in 2002-2004, fall and winters were wetter than average for College Park, Maryland. Since temperature experiments used trends from the 2002-2004 years, we decided to test Polytrichum ohioense with cooler falls and winters.

\subsection{Temperature experiment}

In order to maintain all variables, especially a constant humidity, it was necessary to run these experiments under the most controlled conditions that tissue culture provided. Developmental timing of control plants appeared to only be lagging approximately 3 weeks behind a normal Polytrichum ohioense life cycle in habit. This developmental lag may be due to the constant light source or continued humidity that were the result of the experimental design.

Experimental plants were exposed to average temperatures $2{ }^{\circ} \mathrm{C}$ warmer in the summer portion of the tissue culture life cycle, and $2^{\circ} \mathrm{C}$ colder during the winter portion of the tissue culture life cycle. The overall developmental timing and plant appearance was not affected any more than what was witnessed in the control plants. 


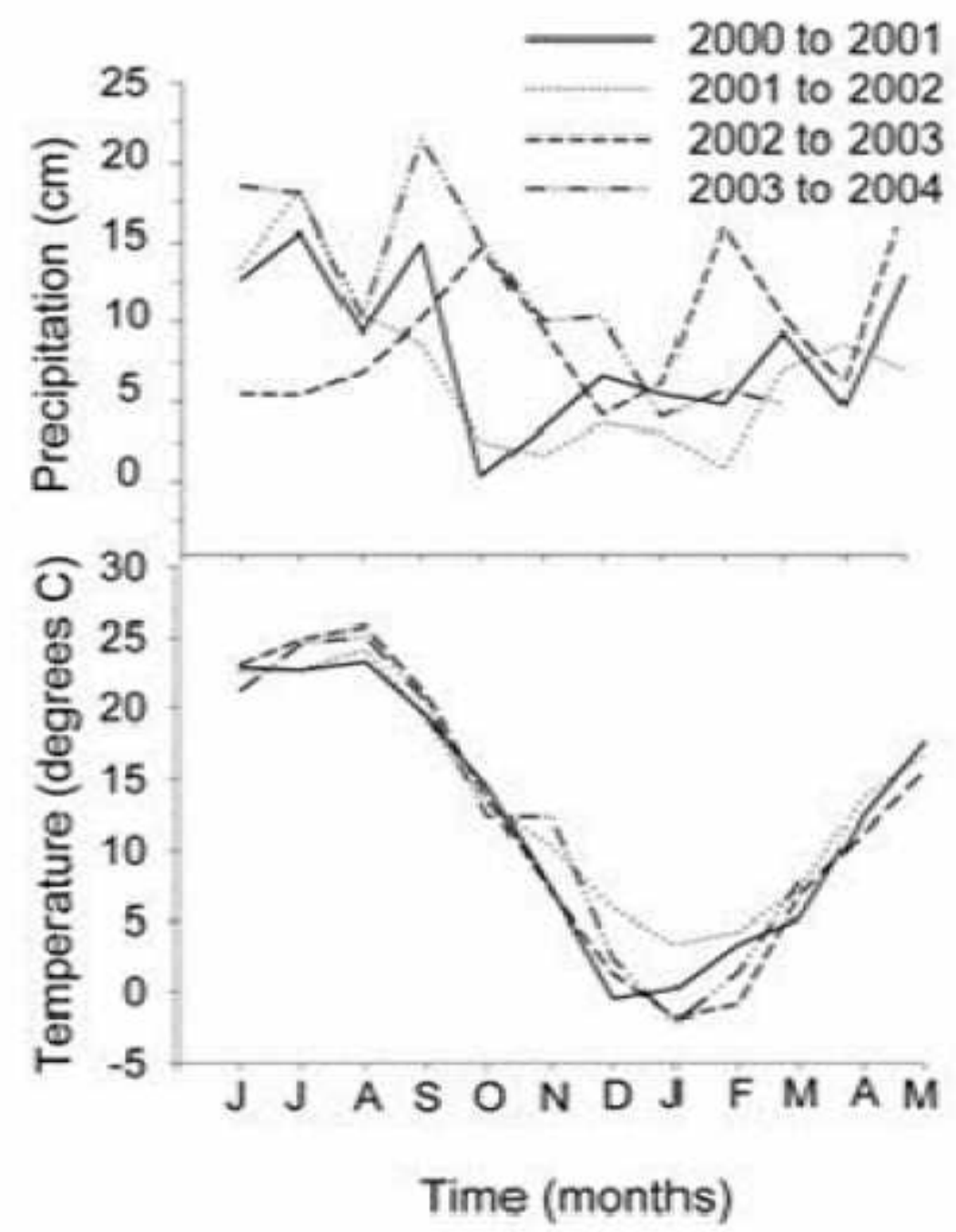

\begin{tabular}{|c|c|c|}
\hline Year & Temperature & Precipitation \\
\hline $2000-2001$ & Average year & Average year round \\
\hline $2001-2002$ & Cool Summer, Warm Winter & Wet Summer, Dry Winter \\
\hline $2002-2003$ & Warm Summer, Cool Winter & Wet Summer, Wet Fall \\
\hline $2003-2004$ & Warm Summer, Cool Winter & Dry Summer, Wet Winter \\
\hline
\end{tabular}

Figure 1: Graphical representation of precipitation and temperature data from the US Climate Change website

When both control and Warm Summer, Cool Winter plants were exposed to $10^{-6} \mathrm{M}$ IAA during the PAT experiments, young control sporophytes exhibited lower basipetal transport than any previous year by at least $10 \mathrm{fmol}$ (Table 1). Acropetal transport in control plants was within the range of previous acropetal transport amounts in young sporophytes (Table1). The Warm Summer, Cool Winter sporophytes, showing similar basipetal and acropetal transport amounts as the control sporophytes (Table 2), exhibited lower transport data than previous years (Table 1). These differences were within $4-40 \%$ less, not over $500 \%$.
Table 2: PAT in young sporophytes of Polytrichum ohioense after being treated to average yearly temperatures for Maryland or a "Warm Summer, Cool Winter" treatment. Notice that neither basipetal nor acropetal transport changes by a significant amount from average temperatures for the same location.

\begin{tabular}{|c|c|c|c|c|}
\hline $\begin{array}{c}\text { Transport } \\
\text { Direction }\end{array}$ & \multicolumn{2}{|c|}{$\begin{array}{c}\text { Warm Summer, Cool } \\
\text { Winter Treatment }\end{array}$} & \multicolumn{2}{|c|}{ Average Treatment } \\
\cline { 2 - 5 } & $\begin{array}{c}\text { Transport } \\
\text { (fmoles) }\end{array}$ & $\begin{array}{c}\text { Replicate } \\
\text { Number }\end{array}$ & $\begin{array}{c}\text { Transport } \\
\text { (fmoles) }\end{array}$ & $\begin{array}{c}\text { Replicate } \\
\text { Number }\end{array}$ \\
\hline Basipetal & $52.3 \pm 22.3$ & 10 & $49.6 \pm 15.8$ & 9 \\
\hline Acropetal & $5.5 \pm 0.5$ & 13 & $6.2 \pm 1.1$ & 11 \\
\hline
\end{tabular}


In conclusion, the sporophytes from the temperature trials did not show the same large increase or decrease that was witnessed in the 2003-2004 samples. However, there were some differences in transport amounts that could suggest that PAT may be slightly temperature dependent.

\subsection{Precipitation experiment}

Variables were held constant for this experiment in a different way than the temperature experiment because in order to vary moisture availability, we needed to water plants easily and without compromising the design. Therefore, tissue culture was not an option for this experiment. Plants grown in the growth chamber were not developmentally delayed from Polytrichum ohioense growing in nature.

Experimental sporophyte were exposed to 0.8 in./month more water during the Fall portion of their development cycle, and 0.9 in./ month more water during the Winter portion of their development cycle. This increase in water availability during three month intervals increased basipetal transport in experimental sporophytes by 4.3 times but acropetal transport did not change more than 1.5 times than the control plants (Table 3). When compared to the original data from 20002004, this treatment did increase transport at a more significant amount similar to the 2003-3004 trials suggesting that water availability does impact PAT in Polytrichum ohioense (Table $1)$.

Table 3: PAT in young sporophytes of Polytrichum ohioense after being treated to average yearly precipitation for Maryland. Notice that precipitation change mimicked the data from the 2003-2004 growing season suggesting precipitation is a critical factor affecting PAT quantities.

\begin{tabular}{|c|c|c|c|c|}
\hline \multirow{2}{*}{$\begin{array}{c}\text { Transport } \\
\text { Direction }\end{array}$} & \multicolumn{2}{|c|}{ Wet Winter Treatment } & \multicolumn{2}{|c|}{ Average Treatment } \\
\cline { 2 - 5 } & $\begin{array}{c}\text { Transport } \\
\text { (fmoles) }\end{array}$ & $\begin{array}{c}\text { Replicate } \\
\text { Number }\end{array}$ & $\begin{array}{c}\text { Transport } \\
\text { (fmoles) }\end{array}$ & $\begin{array}{c}\text { Replicate } \\
\text { Number }\end{array}$ \\
\hline Basipetal & $265 \pm 42.1$ & 12 & $61.6 \pm 5.5$ & 12 \\
\hline Acropetal & $4.7 \pm 0.8$ & 12 & $7.0 \pm 1.2$ & 10 \\
\hline
\end{tabular}

\section{Conclusion}

Polytrichum ohioense sporophytes grow as a bipolar structure with apical cells at either end and an intercalary meristem at the base of a future capsule [45], [46], [47], [48]. The seta is comprised of several cell layers and requires substantial cell differentiation to mature and the complexity of axial development in a seemingly simple, short lived structure should require regulation that is provided by auxin transport [32].

This work does demonstrate that not all environmental factors are of equal importance to PAT physiology. Temperature does seem to cause PAT rates to vary slightly, but water availability provides a larger influence on the system's development. Future studies that can examine a combination of temperature and humidity would provide a real life scenario, but also confirm the synergistic effects of variables.

This work may not be critical to understanding the importance of temperature or water availability during moss growth and development, but it does provide us with real time physiological stress data on a population using PAT assays. It also allows even small changes in yearly climate to be measured accurately. To make this system more comprehensive, researchers could pool data for similar species and use the data for environmental, ecological, and evolutionary monitoring. The need for a small sample size necessary for data production (less than 40 plants) creates a protocol that leaves less environmental impact and is relatively easy to do with minimal equipment needs. The protocol is also inexpensive once a scintillation counter is available. Our experiments equate to reliable ways gain data on environmental changes or impacts from disasters.

\section{Acknowledgments}

The authors would like to thank Sarah Petrosky for her help with the figures and proofreading of the manuscript. This work was supported by grants from Roanoke College and the Thomas F. and Kate Miller Jeffress Memorial Trust.

\section{References}

[1] A. Santner, L. Calderon-Villalobos, M. Estelle Review: Plant hormones are versatile chemical regulators of plant growth. Nature Chemical Biology 2009;5(5):301-307, DOI: 10.1038/nchembio.165

[2] A. Woodward, B. Bartel. Review: Auxin: Regulation, action, and interaction. Annals of Botany

\section{5;95:707-735, DOI: 10.1093/aob/mci083}

[3] Cleland, RE. Auxin and cell elongation. In Plant hormones and their role in plant growth and development $2^{\text {nd }}$ ed. PJ Davies, [ed.], 1995. DOI 10.1007/978-94-011-0473-9-10

A. Rashotte, S. Brady, R. Reed, S. Ante, G. Muday. Basipetal auxin transport is required for gravitropism in roots of Arabidopsis. Plant Physiology 2000;122:481-490. DOI: http://dx.doi.org/10.1104/ pp.122.2.481

[5] D. Reinhardt, E. Pesce, P.. Stieger, T. Mandel, K. Baltensperger, M. Bennett, J. Traas, J. Friml, J. Kuhlemeier. Regulation of phyllotaxis by polar auxin transport. Nature 2003;426:255-260, DOI:10.1038/nature02081

[6] S. Lau, G. Jürgens, I. De Smet. Review: The evolving complexity of the auxin pathway. The Plant Cell 2008;20:1738-1746, DOI:i http://dx.doi.org/10. $1105 /$ tpc. 108.060418

[7] B. Möller, D. Weijers. Auxin control of embryo patterning. Cold Spring Harb Perspect Biol. 2009;1:a001545:1-12,

DOI: $10.1101 /$ cshperspect.a001545

[8] L. Nyman, E. Cutter. Auxin-cytokinin interaction in the inhibition, release, and morphology of gametophore buds of Plagiomnium cupidatum from apical dominance. Canadian Journal of Botany 1981;59:750-760, DOI: 10.1139/b81-106

[9] S. Rose, P. Rubery, M. Bopp. The mechanism of auxin uptake and accumulation in moss protonemata. Physiologia Plantarum 1983;58:52-56, DOI: 10.1111/j.1399-3054.1983.tb04142.x 
[10] S. Rose, M. Bopp. Uptake and polar transport of indoleacetic acid in moss rhizoids. Physiologia Plantarum 1983;58:57-61, DOI: 10.1111/j.13993054.1983.tb04143.x

[11] R. Chopra, B. Vashistha. The effect of auxins and antiauxins on shoot-bud induction and morphology in the moss, Bryan atrovirens Will. ex Brid. Australian Journal of Botany 1990;38:177-184, DOI:10.1071/BT9900177

[12] U. Geier, O. Werner, M. Bopp. Indole-3-acetic acid uptake in isolated protoplasts of the moss Funaria hygrometrica. Physiologia plantarum 1990;80:584592, DOI: http://dx.doi.org/10.1034/j.13993054.1990.800414.x

[13] K. Kaul, G. Mitra, B. Tripathi. Responses of Marchantia in aseptic culture to well-known auxins and antiauxins. Annals of Botany 1962;26:447-467.

[14] N. Maravolo, P. Voth. Morphogenic effects of three growth substances on Marchantia gemmalings. Botanical Gazette 1966;127:79-86.

[15] G. Davidonis, M. Munroe. Apical dominance in Marchantia: correlative inhibition of neighbor lobe growth. Botanical Gazette 1972;133:177-184, DOI: http://dx.doi.org/10.1086/336631

[16] L. Stange. Meristem differentiation in Riella helicophylla (Bory et Mont.) Mont. Under the influence of auxin and anti-auxin. Planta 1977;135:289-295.

[17] S. Kumra, R. Chopra. Callus initiation, its growth and differentiation in the liverwort Asterella wallichiana (Lehm. et Lindenb.) Groelle I. Effect of auxins and cytokinins. Journal of the Hattori Botanical Laboratory 1987;63:237-245. DOI: 10.1007/BF00384902

[18] Lomax TL., Muday GK., Rubery PH. (1995) Auxin transport. In: P. J. Davies [ed.], Plant hormones, 509530. Kluwer, Dordrecht, Netherlands. DOI: 10.1007/978-94-011-0473-9_24

[19] R. Swarup, J. Friml, A. Marchant, K. Ljung, G. Sandberg, K. Palme, M. Bennett. Localization of the auxinpermease AUX1 suggests two functionally distinct hormone transport pathways operate in the Arabidopsis root apex. Genes Dev. 2001;15:26482653., DOI:10.1101/gad.210501

[20] V. Imhoff, P. Muller, J. Guern, A. Delbarre Inhibitors of the carrier-mediated influx of auxin in suspension-cultured tobacco cells. Planta 2000;210:580-588, DOI: 10.1007/s004250050047

[21] A. Muller, C. Guan, L. Galweiler, P. Tanzeler, P. Huijser, A. Marchant, G. Parry, M. Bennet, E. Wiseman, K. Palme. AtPIN2 defines a locus of Arabidopsis for root gravitropism control. EMBO Journal DOI: 10.1093/emboj/17.23.6903
[23] J. Friml, E. Benkova, I. Blilou, J. Wisniewska, T. Hamman, K. Llung, S. Woody, G. Sandberg, B. Scheres, G. Jurgens, K. Palme. AtPIN4 mediates sink-driven auxin gradients and root patterning in Arabidopsis. Cell 2002;108:661-673, DOI: http://dx.doi.org/10.1016/S00928674(02)00656-6

[24] M. Geisler, j. Blakeslee, R. Bouchard, O. Lee, V. Vincenzetti, A. Bandyopadhyay, W. Peer, E. Richards, K. Ejendal. Cellular efflux of auxin mediated by the Arabidopsis MDR/ PGP transporter at PGP1. Plant J 2005;44:179-194, DOI: 10.1111/j.1365-313X.2005.02519.X

[25] J. Wiśniewska, J. Xu, D. Seifertová, P. Brewer, K. Růžička, I. Blilou, D. Rouquié, E. Benková, B. Scheres, J. Friml. Polar PIN localization directs auxin flow in plants. Science 2006;312:883, DOI: $10.1126 /$ science. 1121356

[26] J. Blakeslee, A. Bandyopathyay, O. Lee, J. Mravec, B. Titapiwatanakun, M. Sauer, S. Makam, Y. Cheng, R. Bouchard, J. Adamec, M. Geisler, A. Nagashima, T. Sakai, E. Martinoia, J. Friml, W. Peer, A Murphy. Interactions among PIN-FORMED and PGlycoprotein auxin transporters in Arabidopsis. The Plant Cell 2007;19(1):131-147, DOI: http://dx.doi. org/10.1105/tpc.106.040782

[27] Cooke, TJ. Poli, DB. Cohen, JB. Did auxin play a crucial role in the evolution of novel body plans during the late Silurian- early Devonian radiation of vascular plants? In A. R. Hemsley and I. Poole (eds.), Evolution of plant physiology, Elsevier Academic Press: Amsterdam, 2002. DOI: 10.1016/B978012339552-8/50006-8

[28] P. Křeček, P. Skůpa, J. Libus, S. Naramoto, R. Tejos, J. Friml, E. Zažímalová Protein family review: The PIN-FORMED (PIN) protein family of auxin transporters. Genome Biology 2009;10:249, DOI:10.1186/gb-2009-10-12-249

[29] N. Maravolo. Polarity and localization of auxin movement in the hepatic, Marchantia polymorpha. American. J. Bot. 1976;63(5):526-531, DOI: http://dx.doi.org/10.2307/2441816

[30] D. Gaal, S. Dufresne, N. Maravolo. (1982) Transport of ${ }^{14} \mathrm{C}$-indoleacetic acid in the hepatic Marchantia polymorpha. The Bryologist 1982;85:410-418, DOI: http://dx.doi.org/10.2307/3242908

[31] T. Cooke, D. Poli, A. Sztein, J. Cohen. Evolutionary patterns in auxin action. Plant Molecular Biology 2002;49:319-338, DOI:10.1007/978-94-010-037735

[32] D. Poli, M. Jacobs, T. Cooke. Auxin regulation of axial growth in bryophyte sporophytes: its potential significance for the evolution of early land plants. American J Bot 2003;90:1405-1415, DOI:10.3732/ajb.90.10.1405

[33] T. Fujita, H. Sakaguchi, Y. Hitwatashi, S. Wagstaff, M. Ito, H. Deguchi, T. Sato, M. Hasebe. Convergent evolution of shoots in land plants: lack of polar auxin transport in moss shoots. Evolution \& Development 2008;10(2):176-186, 142X.2008.00225.X
DOI: $10.1111 / \mathrm{j} .1525$ - vascular tissue. Science 1998; 282(5397):2226-223, DOI: $10.1126 /$ science.282.5397.2226 
[34] J. Friml. Auxin transport - shaping the plant. Current Opinion in Plant Biology 2003;6(1):7-12, DOI: $10.1016 / \mathrm{S} 1369526602000031$

[35] G. Rothwell, S. Lev-Yadun. Evidence of polar auxin flow in 375 million-year-old fossil wood. Am. J. Bot. 2005;92(6):903-906, DOI 10.3732/ajb.92.6.903

[36] J. Poikolainen, E. Kubin, J. Piispanen, J. Karhu. Atmospheric heavy metal deposition in Finland during 1985-2000 using mosses as bioindicators. Science of the Total Environment 2004;318(13):171-185, DOI: 10.1016/S0048-9697(03)00396-6

[37] J. Schilling, M. Lehman. Bioindication of atmospheric heavy metal deposition in the Southeastern US using the moss Thuidium delicatulum. Atmospheric Environment 2002;36(10):1611-1618, DOI: 10.1016/S13522310(02)00092-4

[38] A. Siebert, I. Bruns, G-J.. Krauss, J. Miersch, B. Markert. The use of the aquatic moss Fontinalis antipyretica L. ex Hedw. As a bioindicator for heavy metals: 1. Fundamental investigations into heavy metal accumulation in Fontinalis antipyretica L. ex Hedw. Science of The Total Environment 1996;177(1-3):137-144, DOI: $\quad 10.1016 / 0048$ 9697(95)04891-X

[39] M. Schintu, A. Cogoni, L. Durante, C. Cantaluppi, A. Contu. Moss (Bryum radiculosum) as a bioindicator of trace metal deposition around an industrialised area in Sardinia (Italy). Chemosphere 2005;60(5):610-618, DOI: 10.1016/j.chemosphere.2005.01.050

[40] T. Lim, R. Xu, B. Tan, J. Obbard. Persistent organic pollutants in moss as bioindicators of atmospheric pollution in Singapore. Chemosphere 2006;64(4):596-602, DOI:

10.1016/j.chemosphere.2005.11.007
[41] F. Palmieri, R. Neri, C. Benco, L. Serracca. Lichens and moss as bioindicators and bioaccumulators in air pollution monitoring. $\mathbf{J}$ of Envi Pathology, Toxicology, and Oncology 1997;16(2-3):175-190, DOI: 10.1016/S0269-7491(00)00224-4

[42] M. Sonesson, B. Carlsson, T. Callaghan, S. Halling, L. Bjorn, M. Bertgren, U. Johanson. Growth of two peat-forming mosses in subarctic mires: species interactions and effects of simulated climate change. Oikos 2002;99:151-160, DOI: 10.1034/j.16000706.2002.990115.x

[43] C. McCready, W. Jacobs. Movement of growth regulators in plants. II. Polar transport of radioactivity from indoleacetic acid- $\left[{ }^{14} \mathrm{C}\right]$ and 2,4-dichlorophenoxyacetic acid- $\left[{ }^{14} \mathrm{C}\right]$ in petioles of Phaseolus vulgaris. New Phytologist 1963;62:19-34, DOI: 10.1111/j.1469-8137.1963.tb06308.x

[44] Mitchell J., Livingston G. Methods of studying plant hormones and growth-regulating substances. Agriculture Handbook \# 336, Agriculutral Research Service, United States Department of Agriculture, Washington DC, 1986.

[45] Smith G. Cryptogamic botany: bryophytes and pteridophytes, vol. II, $2^{\text {nd }}$ ed., McGraw-Hill, New York, 1955

[46] M. Lal, N. Bhandari. The development of sex organs and sporophyte in Physcomitrium cyathicarpum Mitt. Bryologist 1968;71:11-20

[47] Bold H, Alexopoulos C, Delevoryas T. Morphology of plants and fungi, $5^{\text {th }}$ ed. Harper \& Row, New York, New York, 1987. DOI: 10.2307/1221872

[48] Crum H. Structural diversity of bryophytes. University of Michigan Herbarium, Ann Arbor, Michigan, 2001.

[49] J. French, D. Paolillo. Intercalary meristematic activity in the sporophyte of Funaria (Musci). American J. of Botany 1975;62:86-96, DOI: http://dx.doi.org/10.2307/2442082 